\title{
FAKTOR-FAKTOR PENERIMAAN INDIVIDU DALAM IMPLEMENTASI TI DI PEMERINTAH KOTA BOGOR
}

\author{
Layungsari, Putu Wuri Handayani, Yova Ruldeviyani
}

\author{
Program Studi Magister Teknologi Informasi, Fakultas Ilmu Komputer, Universitas Indonesia, Jl. \\ Salemba Raya No.4, Jakarta Pusat, Indonesia \\ E-mail: layungsari_bibisono@yahoo.com
}

\begin{abstract}
The use of Information Technology (IT) in public sector organizations cannot always be applied properly. This could lead to failure of Information Systems. Many literature states that successful implementation of an information system is very dependent on the acceptance level of the system by its users. The Government of Bogor City as a public sector organization in Indonesia has been active in the development of IT. From 2008 to 2013, the Government of Bogor City developed nine application, four of which has running with low utilization and the other five applications no longer operate as a result of very minimum user. This study analyzes the individual factors that influence the acceptance of implementation of IT in the Government Environment using TAM. This is quantitative Survey Research using sample of 410 employees of Bogor city. Data processing was performed using descriptive statistical techniques and PLS-SEM. The results prove that the Perceived Usefulness and Perceived Ease of Use has a significant influence on the Behavioral Intention to use IT at Government of Bogor City. Behavioral Intention has a significant influence on the Actual IT Use and Perceived Ease Perceived Ease of Use had a significant effect on the Perceived Usefulness.
\end{abstract}

Keywords: Government of Bogor City, IT Acceptance, PLS-SEM, Public Sector Organization, TAM

\begin{abstract}
Abstrak
Penggunaan Teknologi Informasi (TI) pada Organisasi sektor publik tidak selalu dapat diterapkan dengan baik dan dapat berujung pada kegagalan Sistem Informasi. Berbagai literatur menyebutkan terdapat hubungan antara kegagalan penerapan TI dengan penerimaan pengguna. Pemerintah Kota Bogor sebagai organisasi sektor publik giat dalam pengembangan TI, dari beberapa aplikasi yang dikembangkan pada tahun 2008 - 2013, empat aplikasi memiliki tingkat utilisasi yang rendah (kurang dari $80 \%$ ) dan lima aplikasi lainnya tidak lagi dioperasikan akibat rendahnya penggunaan sehingga sejumlah proses kembali dilakukan secara manual. Penelitian ini menganalisis faktor-faktor yang mempengaruhi penerimaan individu dalam implementasi TI di Pemerintah Kota Bogor menggunakan model penerimaan TAM karena TAM dapat digunakan sebagai dasar model penerimaan TI untuk memprediksi niat penggunaan TI pada pegawai pemerintah di sebagian besar kota di Indonesia. Metodologi yang digunakan berupa Survey Research dan bersifat kuantitatif dengan jumlah responden sebanyak 410 pegawai Pemerintah Kota Bogor. Pengolahan data dilakukan menggunakan teknik statistika deskriptif dan PLS-SEM. Hasil pengolahan data membuktikan bahwa Persepsi Kegunaan dan Persepsi Kemudahan Penggunaan memiliki pengaruh yang signifikan terhadap niat menggunakan TI pada Pemerintah Kota Bogor. Niat menggunakan TI memiliki pengaruh yang signifikan terhadap penggunaan TI, dan Persepsi Kemudahan Penggunaan memiliki pengaruh yang signifikan terhadap Persepsi Kegunaan.
\end{abstract}

Kata Kunci: Organisasi Sektor Publik, Pemerintah Kota Bogor, Penerimaan TI, PLS-SEM, TAM

\section{Pendahuluan}

Penggunaan Teknologi Informasi (TI) dewasa ini telah menjadi bagian dari bergeraknya sebuah organisasi. TI dapat berperan sebagai pendukung pekerjaan dalam organisasi sehari-hari maupun sebagai pemberdaya yang dapat membantu tercapainya tujuan bisnis organisasi. Tujuan penggunaan TI adalah untuk meningkatkan efisiensi dan efektifitas dalam menyelesaikan pekerjaan serta memberi pelayanan yang lebih kepada pelanggan sehingga dapat memperoleh keunggulan daya saing yang berujung pada tercapainya tujuan bisnis organisasi seperti keuntungan finansial. Pada organisasi sektor publik, penerapan TI lebih ditujukan untuk dapat meningkatkan pelayanan kepada masyarakat selain untuk dapat mendukung terwujudnya cita-cita pembangunan. 
Dalam penerapannya, implementasi TI pada organisasi baik sektor privat maupun publik tidak selalu berujung pada keberhasilan. Fakta menunjukan sebagian besar proyek implementasi TI mengalami kegagalan baik secara total maupun sebagian [1]. Walaupun sebagian kegagalan implementasi TI disebabkan karena lemahnya manajemen, berbagai literatur menyatakan bahwa terdapat hubungan yang signifikan antara kegagalan atau keberhasilan implementasi TI pada suatu organisasi dengan sikap / perilaku pengguna terhadap penerimaan sistem pada organisasi tersebut [2]. Menurut Venkatesh et al. [10] dalam Yamin \& Lee [3], keberhasilan implementasi TI sebagian besar bergantung pada tingkat penerimaan sistem oleh penggunanya.

Pemerintah Kota Bogor yang memiliki perhatian cukup besar terhadap peningkatan layanan publik dan kualitas sumber daya manusia juga turut giat dalam sejumlah inisiasi dan implementasi TI. Hal ini sesuai dengan Instruksi Presiden RI Nomor 6 Tahun 2001 tentang Pengembangan dan Pendayagunaan Telematika di Indonesia serta Instruksi Presiden Nomor 3 Tahun 2003 tentang Strategi dan Kebijakan Nasional Pengembangan E-Government. Tidak semua penerapan TI di Kota Bogor berujung pada keberhasilan, beberapa diantaranya mengalami hambatan dalam hal pemanfaatannya. Aplikasi Kantaya yang sejatinya merupakan sarana bagi aparatur Kota Bogor untuk dapat berkomunikasi maupun berkorespondensi secara elektronik sepi dari pengguna sehingga tidak dioperasikan kembali, begitu pula dengan salah satu sistem aplikasi pelaporan (SIBANG) di Bagian Pengendalian Program Sekretariat Daerah, sempat diimplementasikan pada tahun 2010 namun pada tahun 2011 juga terhenti pengoperasiannya akibat dari penggunanya yang semakin lama semakin berkurang sehingga mekanisme pelaporan kembali dilakukan secara manual. SIM Hibah Bansos yang memiliki operator dari 22 Organisasi Perangkat Daerah (OPD), sampai hampir satu tahun pengimplementasiannya tercatat hanya operator dari 2 OPD yang menginput data ke dalam sistem. Sistem Aplikasi Pelayanan Perijinan (SISAPP) yang digunakan operator layanan pada Badan Pelayanan Perijinan Terpadu dan Penanaman Modal (BPPTPM) juga tidak termanfaatkan sepenuhnya. Terdapat fitur-fitur layanan perijinan tertentu pada sistem ini yang tidak dimanfaatkan walaupun seluruh operator menggunakan sistem aplikasi ini dalam memberikan layanan perijinan kepada masyarakat. Sumber dari BPPTPM menyatakan bahwa tingkat penggunaan SISAPP kurang lebih sebesar $75 \%$. Tidak digunakannya beberapa fitur pada sistem ini disebabkan kurangnya sumber daya manusia khususnya operator TI untuk melayani proses perijinan tertentu tersebut, serta kurangnya jumlah pengajuan proses perijinan tertentu tersebut sehingga operator layanan lebih memilih memberikan pelayanan dengan cara manual. Aplikasi SIMTAKA (Sistem Informasi Tata Naskah) untuk mendisposisi surat pada Dinas Pendapatan Daerah (Dispenda) juga hanya terutilisasi $40 \%$ sehingga sebagian besar proses disposisi dan surat menyurat pada Dinas ini masih dilakukan secara manual walaupun telah ada kebijakan pada internal Dispenda untuk mengimplementasikan SIMTAKA.

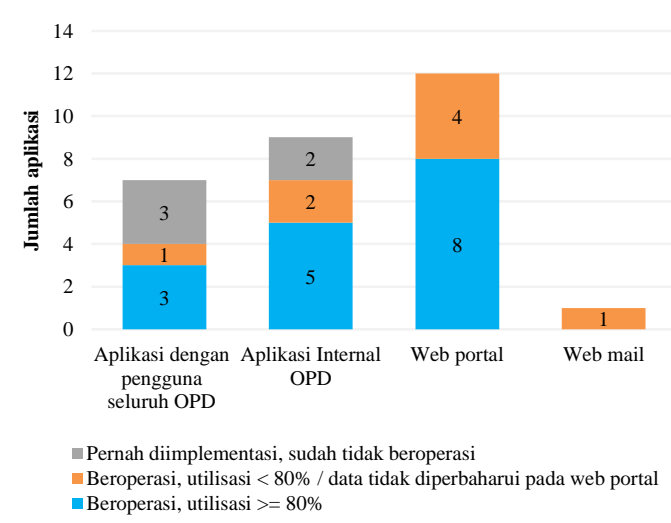

Gambar 1. Jumlah aplikasi dan utilisasi penggunaan aplikasi di Pemkot Bogor (2008-2013)

Gambar 1 menunjukan adanya kendala dalam pemanfaatan sistem aplikasi ataupun web yang pernah dibuat. Empat aplikasi dengan pengguna seluruh OPD maupun pada internal OPD memiliki tingkat utilisasi yang rendah (kurang dari 80\%) dan lima aplikasi lainnya tidak lagi dioperasikan akibat dari sepinya pengguna pada aplikasi tersebut. Sejumlah proses kembali dilakukan secara manual karena rendahnya tingkat utilisasi pada aplikasi yang mengotomasi prosesnya, antara lain proses pelaporan kegiatan setiap bulan, pelaporan data barang dan aset daerah, proses validasi hibah dan bansos, serta sebagian proses layanan perijinan. Empat web portal juga tidak termanfaatkan sepenuhnya dengan tidak diperbaharuinya data pada web portal tersebut. Data yang diperoleh dari Kantor Komunikasi dan Informatika Kota Bogor menunjukkan bahwa jumlah akun email resmi yang dibuatkan sejumlah 279 akun, namun tercatat hanya 77 akun yang login ke sistem email pada tahun 2014, sementara 99 akun lainnya tercatat terakhir kali mengakses email resmi pada tahun 2012 dan 2013, sedangkan sisanya tidak pernah ada catatan login ke email resmi Kota Bogor. Hal ini menunjukkan rendahnya tingkat penggunaan email resmi di lingkungan pegawai Pemerintah Kota Bogor yaitu hanya sebesar $25 \%$. 


\section{Tinjauan Teoritis}

Dewasa ini sejumlah pakar telah banyak menciptakan teori dan kajian mengenai penerimaan TI pada sebuah organisasi. Beberapa teori yang banyak digunakan diantaranya adalah Theory of Reasoned Action (TRA), Technology Acceptance Model (TAM), serta Unified Theory of Acceptance and Use of Technology (UTAUT). Secara umum teori-teori tersebut menggambarkan bahwa terdapat sejumlah faktor tertentu yang dapat mempengaruhi individu dalam organisasi untuk mau menggunakan TI. Faktor-faktor tersebut cukup beragam tergantung pada organisasi / studi kasus yang diangkat. Jika faktorfaktor yang mempengaruhi penerimaan implementasi TI pada suatu organisasi ini dapat diketahui lebih dini, hal ini dapat mengurangi tingkat kegagalan atau adanya resistensi pada implementasi TI.

TAM merupakan salah satu teori yang sering digunakan dalam penelitian untuk memahami adopsi TI dan penggunaannya dalam organisasi. Penggunaan TAM telah banyak diterapkan dalam berbagai studi kasus yang berbeda seperti penerimaan teknologi komputer, belanja online, Sistem aplikasi kesehatan, penerapan $e$ Government, dan sebagainya [1]. Teori ini telah menjadi subjek dalam banyak penelitian di bidang sistem informasi selama hampir 20 tahun dengan didukung oleh berbagai studi kasus [4]. TAM dikembangkan oleh Davis et al. [5] pada tahun 1989 dengan konsep dasar yang menyatakan bahwa penggunaan teknologi secara nyata didorong oleh adanya niat untuk menggunakan teknologi tersebut yang dipengaruhi oleh adanya persepsi kemudahan penggunaan (Perseived Ease of Use) dan persepsi kegunaan (Perseived Usefulness). Secara konseptual teori tersebut tampak pada Gambar 2.

Persepsi kemudahan penggunaan dari suatu teknologi (Perceived Ease of Use) mengacu pada kepercayaan pengguna bahwa menggunakan teknologi tersebut tidak akan membutuhkan usaha yang banyak (mudah digunakan). Sedangkan persepsi kegunaan (Perceived Usefulness) dapat diartikan sebagai kepercayaan pengguna bahwa dengan menggunakan teknologi tersebut akan membantu meningkatkan performa dalam bekerja.

Pada penelitiannya, Santoso [7] menyimpulkan bahwa persepsi pengguna terhadap kemudahan dalam penggunaan TI (PEOU) di Kabupaten Sragen memiliki pengaruh yang signifikan terhadap persepsi pengguna terhadap kegunaan TI (PU), serta memiliki pengaruh yang signifikan pula terhadap sikap pengguna (ATT). Persepsi kenyamanan (PE) yang dirasakan oleh pengguna dalam menggunakan TI di Kabupaten
Sragen terbukti memiliki pengaruh yang signifikan terhadap dampak yang dialami seseorang bila menggunakan suatu sistem tertentu dalam pekerjaannya (ATT), hal ini dapat disebabkan oleh sudah terbiasanya para pegawai dalam menggunakan sistem sehingga mungkin dapat menciptakan rasa nyaman dalam melaksanakan pekerjaan dengan menggunakan TI [7]. Putra \& Tjahjono [8] menggunakan 5 (lima) konstruk yang telah dimodifikasi dari model penelitian TAM sebelumnya dalam mengkaji pengaruh sikap (attitude) dan efikasi diri (Self Efficacy) terhadap minat berperilaku (behavior intention) aparatur pemerintah Kota Yogyakarta dalam menggunakan e-Government. Hasil penelitiannya membuktikan bahwa sikap memiliki pengaruh positif terhadap kemudahan, kemudahan memiliki pengaruh positif terhadap manfaat, dan manfaat memiliki pengaruh positif terhadap minat berperilaku, sementara efikasi diri terbukti tidak memiliki pengaruh positif terhadap manfaat dan kemudahan, serta sikap tidak memiliki pengaruh positif terhadap manfaat [8]. Bogar [9] melakukan penelitian tentang penerimaan TI di lingkungan pegawai pemerintahan pada Kabupaten baru hasil pemekaran dari Kabupaten Sangihe yaitu Kabupaten Sitaro (Siau Tagulandang dan Biaro) di Sulawesi. Penelitiannya menggunakan istilah Persepsi Manfaat Dirasakan (PMD) untuk perceived usefulness pada TAM, Persepsi Mudah Penggunaan (PMP) untuk perceived ease of use pada TAM, Sikap Menggunakan (SM) untuk Attitude Toward Using pada TAM serta Penerimaan Teknologi Informasi (PTI) untuk Technology Acceptance. Hasil penelitiannya mengungkapkan bahwa PMD, PMP dan SM berpengaruh langsung terhadap PTI serta PMD dan PMP berpengaruh langsung terhadap SM teknologi informasi [9].

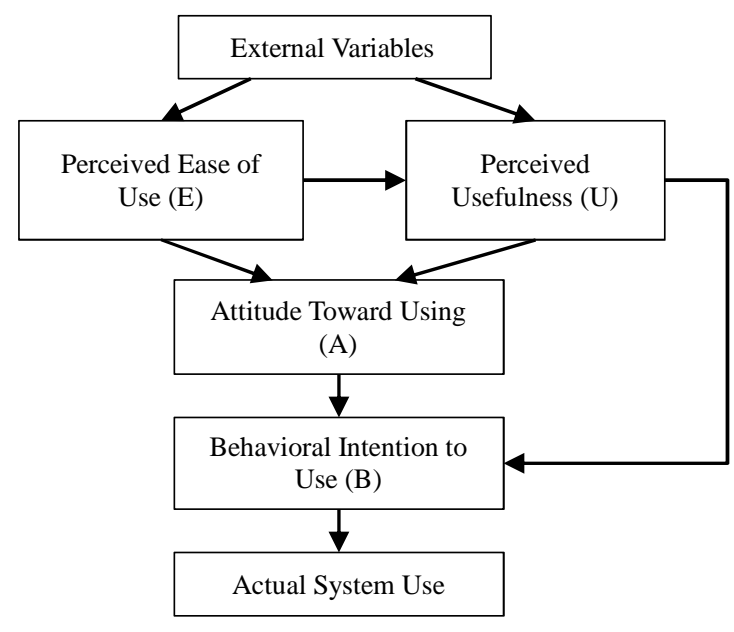

Gambar 2. Technology Acceptance Model (Davis, Bagozzi, \& Warshaw, 1989) 


\section{Metode Penelitian}

Penelitian ini berupa Survey Research bersifat kuantitatif dimana untuk menganalisis fenomena yang ada menggunakan teknik statistik, matematik dan komputasional. Penyusunan hipotesis penelitian didasarkan pada hasil studi literatur serta kerangka pemikiran yang telah dibangun. Hipotesis dibangun dengan memperhatikan variabel bebas yang diduga menjadi faktor penentu dari niat menggunakan TI, diperkuat dengan adanya studi yang mencantumkan hipotesis tersebut. Kuesioner dibuat menggunakan skala likert dari 1-6 yang secara berurutan menunjukan sikap sangat tidak setuju sampai sangat setuju. Teknik pengambilan sampel menggunakan cluster sampling dimana populasi dibagi atas kelompok berdasarkan area/cluster, hal ini dilakukan karena pegawai di Lingkungan Pemerintah Kota Bogor tersebar pada masing-masing unit kerja dengan lokasi yang berbeda sehingga diambil sejumlah sampel untuk mewakili unit kerja masing-masing. Analisis data dilakukan menggunakan metode statistika deskriptif dan statistika inferensial yang berupa Partial Least Square Structural Equation Modelling (PLS-SEM) dengan bantuan perangkat lunak SmartPLS V2.0 M3. Populasi dari penelitian ini adalah pegawai pemerintah Kota Bogor dengan jumlah pegawai mencapai 8850 pegawai yang separuhnya adalah pegawai struktural dan sisanya merupakan pegawai fungsional (guru dan dokter).

TABEL I

INDIKATOR PENELITIAN

\begin{tabular}{lll}
\multicolumn{4}{c}{ INDIKATOR PENELITIAN } \\
\hline Indikator & \multicolumn{1}{c}{ Keterangan } & Sumber \\
\hline PU1 & TI bermanfaat meningkatkan & {$[10]$} \\
PU2 & Performa & {$[10]$} \\
PU3 & TI bermanfaat untuk produktivitas & {$[10]$} \\
PU4 & TI bermanfaat meningkatkan & {$[10]$} \\
PU5 & efektivitas & {$[11]$} \\
PU6 & TI Bermanfaat secara umum & {$[11]$} \\
& TI untuk membuat \\
& keputusan/kebijakan \\
& Dengan TI menjadi lebih cepat \\
PEOU1 & Mudah dalam menggunakan TI & {$[10]$} \\
PEOU2 & Tidak perlu berfikir keras & {$[10]$} \\
PEOU3 & Tidak merasa kesulitan & {$[10]$} \\
PEOU4 & Interaksi dengan TI sangat jelas & {$[10]$} \\
PEOU5 & Mudah untuk menjadi terampil & {$[12]$} \\
BI1 & Akan menggunakan TI & {$[10]$} \\
BI2 & Berniat untuk menggunakan TI & {$[10]$} \\
BI3 & Berencana menggunakan TI & {$[10]$} \\
BI4 & Minat untuk merekomendasikan & {$[10]$} \\
& TI & \\
AU1 & Frekuensi penggunaan & {$[11]$} \\
AU2 & Lamanya waktu pengguanan & {$[11]$} \\
\hline
\end{tabular}

Penelitian ini menggunakan kuesioner sebagai metode pengumpulan data yang disebar kepada 500 responden yaitu pegawai struktural di lingkungan pemerintah Kota Bogor yang tersebar di beberapa Organisasi Perangkat Daerah (OPD). Intrumen penelitian mengacu kepada penelitian sebelumnya dengan menggunakan empat variabel yaitu Perceived Usefulness yaitu tingkat kepercayaan individu bahwa dengan menggunakan sistem akan meningkatkan performa pekerjaan [5]; Perceived Ease of Use yaitu tingkat kepercayaan individu bahwa penggunaan sistem akan dapat dilakukan dengan mudah dan tanpa usaha yang berarti [5][10]; Behavioral Intention To Use yaitu niat/minat dalam menggunakan TI [5]; serta Actual Use yaitu penggunaan TI secara nyata [5]. Indikator pada masing-masing variabel tampak pada Tabel 1 .

\section{Hasil Penelitian}

Dari 500 buah kuesioner yang disebar, terkumpul sebanyak 413 data kuesioner. Hal ini menunjukkan tingkat pengembalian data sebesar 82,6\%. Dari ke-413 data tersebut, 3 kuesioner kembali dalam bentuk tidak lengkap sehingga dikeluarkan dari proses pengolahan data. Ringkasan dari karakteristik demografi responden pada penelitian ini tampak pada Tabel 2.

Dalam hal penggunaan teknologi informasi di lingkungan kerja, responden dimintai informasi tentang frekuensi penggunaan TI di lingkungan kerja, jumlah waktu yang digunakan untuk mengakses TI, jenis aplikasi yang digunakan, serta jenis pekerjaan yang memerlukan keterlibatan TI. Hasil pengolahan data menunjukkan bahwa sebagian besar responden cukup sering menggunakan TI di lingkungan kerja yaitu beberapa kali dalam satu hari $(61,7 \%)$ dengan waktu penggunaan dalam satu hari lebih dari tiga jam $(45,1 \%)$. Ringkasan dari penggunaan teknologi informasi oleh responden penelitian ini tampak pada Tabel 3 .

Jenis aplikasi TI yang lebih banyak banyak digunakan di Pemkot Bogor berupa penggunaan aplikasi perkantoran untuk pengolah kata/angka, dilanjutkan dengan penggunaan internet serta penggunaan email yang berada di urutan ketiga teratas. Dikaitkan dengan banyaknya kegiatan berkomunikasi/berkorespondensi yang dilakukan menggunakan TI serta banyaknya penggunaan email oleh responden, hal ini bertolak belakang dengan data tingkat penggunaan email resmi Pemerintah Kota Bogor yang rendah di kalangan pegawai, dengan demikian ada kemungkinan penggunaan email oleh responden dilakukan menggunakan email lain selain email resmi dan hal ini sangat disayangkan mengingat untuk urusan pekerjaan seyogyanya segala bentuk komunikasi perlu dilakukan melalui email resmi. 
TABEL II

KARAKTERISTIK DEMOGRAFI RESPONDEN

\begin{tabular}{|c|c|c|}
\hline Demografi & Jumlah & $(\%)$ \\
\hline \multicolumn{3}{|l|}{ Usia : } \\
\hline $20-29$ tahun & 41 & 10 \\
\hline $30-39$ tahun & 200 & 48,78 \\
\hline $40-49$ tahun & 126 & 30,73 \\
\hline$>49$ tahun & 43 & 10,49 \\
\hline \multicolumn{3}{|l|}{ Tingkat Pendidikan : } \\
\hline SMA & 77 & 18,78 \\
\hline Diploma & 40 & 9,76 \\
\hline Sarjana & 199 & 48,56 \\
\hline Pasca Sarjana & 94 & 22,93 \\
\hline
\end{tabular}

\begin{tabular}{lrr}
\hline Masa Kerja : & 60 & 14,63 \\
$<5$ tahun & 226 & 55,12 \\
$5-14$ tahun & 116 & 28,29 \\
$15-30$ tahun & 8 & 1,95 \\
$>30$ tahun & & \\
& & \\
\hline Jabatan : & 299 & 72,93 \\
Staf Pelaksana & 111 & 27,07 \\
Pejabat Eselon & &
\end{tabular}

Organisasi Perangkat Daerah :

Badan Pengelolaan Lingkungan Hidup $\quad 12 \quad 2,93$

Kantor Koperasi dan UMKM

Kantor Kesatuan Bangsa dan Politik $\quad 5 \quad 1,22$

$\begin{array}{lll}\text { Sekretariat DPRD } & 8 & 1,95\end{array}$

Kantor Komunikasi dan Informatika $\quad 8 \quad 1,95$

Badan Pelayanan Perijinan Terpadu $\quad 14 \quad 3,41$

Badan Perencanaan Pembangunan $17 \quad 4,15$

Dinas Perindustrian dan Perdagangan

Badan Pengelolaan Keuangan Aset

Daerah

Badan Kepegawaian Pendidikan

Pelatihan

Sekretariat Daerah

Dinas Kebudayaan dan Pariwisata

Dinas Kependudukan dan Pencatatan

Sipil

Kantor Pemuda dan Olah Raga

Dinas Bina Marga dan Sumber Daya

Air

Dinas Kesehatan

Dinas Kebersihan dan Pertamanan

Inspektorat

Badan Pemberdayaan Masyarakat dan

KB

Dinas Tenaga Kerja, Sosial

Transmigrasi

Dinas Lalu Lintas Angkutan Jalan

Dinas Pendapatan Daerah

Dinas Pengawasan Bangunan

Permukiman

Kec. Bogor Barat

Kec. Bogor Tengah

Rumah Sakit Umum Daerah

Satuan Polisi Pamong Praja

Dinas Pertanian

Dins Pendidikan

Analisis menggunakan model persamaan struktural (SEM) dilakukan dengan menelaah model pengukuran dan model struktural yang dibentuk. Model pengukuran memperlihatkan hubungan antara suatu variabel laten dengan indikator pengukurnya, sedangkan model strukural memperlihatkan hubungan antar sesama variabel laten. Pada penelitian ini dibangun model persamaan struktural yang terdiri dari empat variabel laten (PU / Perceived Usefulness, PEOU / Perceived Ease of Use, BI / Behavior Intention, AU / Actual Use) dengan masing-masing indikator pengukurnya (PU1-PU6, PEOU1PEOU5, BI1-BI4, AU1-AU2. Gambar 3 memperlihatkan hasil algoritma PLS yang dihasilkan oleh perangkat lunak SmartPLS.

TABEL III

PENGGUNAAN TEKNOLOGI INFORMASI PADA RESPONDEN

\begin{tabular}{lc} 
& $\begin{array}{c}\text { Persentase } \\
\text { Responden }\end{array}$ \\
\hline Jenis Aplikasi : & \\
Aplikasi perkantoran pengolah data/kata & $86,10 \%$ \\
Basis data & $11,22 \%$ \\
Internet & $67,56 \%$ \\
Email & $49,27 \%$ \\
Sistem Informasi lainnya & $15,85 \%$ \\
\hline Jenis Kegiatan yang menggunakan TI : & \\
Membuat laporan & $75,85 \%$ \\
Membuat surat / disposisi & $41,95 \%$ \\
Mengakses / menyimpan data & $75,85 \%$ \\
Membuat keputusan & $12,68 \%$ \\
Berkomunikasi / Berkorespondensi & $47,56 \%$ \\
Menganalisis permasalahan / alternatif & $30,49 \%$ \\
Penganggaran & $30,49 \%$ \\
\hline Frekuensi Penggunaan : & \\
Kurang dari satu kali dalam satu bulan & $1,23 \%$ \\
Satu kali dalam satu bulan & $2,22 \%$ \\
Beberapa kali dalam satu bulan & $7,64 \%$ \\
Beberapa kali dalam satu minggu & $11,08 \%$ \\
Satu kali sehari & $8,13 \%$ \\
Beberapa kali dalam satu hari & $69,7 \%$ \\
\hline Jumlah waktu penggunaan dalam & \\
hari : & \\
Hampir tidak pernah & \\
Kurang dari 1/2 jam & $1,73 \%$ \\
1/2 jam - 1 jam & $2,72 \%$ \\
1 - 2 jam & $10,12 \%$ \\
Lebih dari 3 jam & $16,30 \%$ \\
\hline & $51,60 \%$ \\
\hline & \\
\hline & \\
\hline & \\
\hline
\end{tabular}

Analisis model pengukuran dilakukan dengan menguji validitas dan reliabilitas instrumen penelitian. Untuk mengetahui tingkat validitas instrumen penelitian digunakan kriteria convergen validity dan discriminant validity. Validitas convergent berhubungan dengan prinsip bahwa pengukur-pengukur (manifes variabel) dari suatu konstruk seharusnya berkorelasi tinggi, sedangkan validitas discriminant berhubungan dengan prinsip bahwa pengukur-pengukur (manifes) konstruk yang berbeda seharusnya tidak berkorelasi dengan tinggi. Suatu indikator dikatakan valid sebagai sebagai pengukur dari variabel laten tersebut jika memiliki nilai korelasi (loading) di atas 0.7. Convergent Validity juga dapat diukur dengan memeriksa nilai Average Variance Extracted (AVE) pada masing-masing konstruk / variabel laten. Suatu variabel laten dikatakan valid jika memiliki nilai AVE > 0,5 
[13]. Tabel 4 memperlihatkan bahwa keseluruhan indikator penelitian memiliki nilai loadings di atas 0,7 sehingga dapat dikatakan bahwa semua indikator yang digunakan valid dalam mengukur masing-masing variabel latennya. Nilai AVE untuk masing-masing variabel laten juga > 0,5 sehingga dapat dikatakan bahwa semua variabel laten memiliki convergen validity yang tinggi.

Pengujian discriminant validity dapat dilihat dengan membandingkan akar AVE untuk setiap konstruk dengan korelasi antara konstruk yang satu dengan konstruk lainnya dalam model penelitian. Jika akar AVE untuk setiap konstruk lebih besar daripada korelasi antar konstruk dengan konstruk lainnya dalam model penelitian, maka hal itu menunjukkan bahwa model mempunyai validitas diskriminan yang baik. Tabel 5 memperlihatkan nilai akar AVE dari masing-masing variabel dan nilai korelasi antar konstruk. Dari Tabel 5 terlihat bahwa nilai akar AVE pada masing-masing variabel laten / konstruk lebih besar dari nilai korelasi antara konstruk tersebut dengan konstruk lainnya, sehingga dapat dikatakan bahwa semua variabel laten dalam model penelitian memiliki validitas diskriminan yang baik. Dengan tingginya validitas diskriminan yang dimiliki seluruh konstruk maka tidak perlu ada perubahan hubungan/tanda panah yang menghubungkan indikator dengan konstruk tertentu pada model.

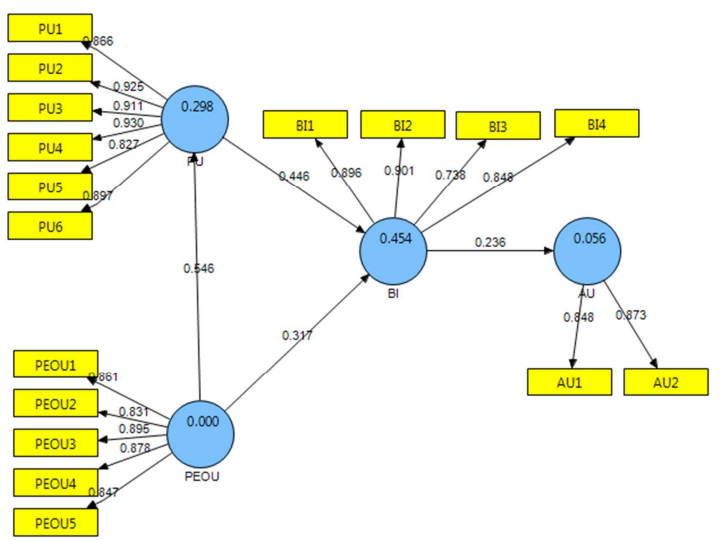

Gambar 3. Hasil algoritma PLS

TABEL IV

ANalisis Model PenguKuran dan Model Struktural

\begin{tabular}{|c|c|c|c|c|c|c|c|}
\hline Konstruk & Indikator & Loadings & $\begin{array}{l}\text { Composite } \\
\text { Reliability }\end{array}$ & $\begin{array}{c}\text { Cronbach } \\
\text { Alpha }\end{array}$ & Ave & Akar Ave & R Square \\
\hline \multirow[t]{6}{*}{$\mathrm{PU}$} & PU1 & 0,866 & 0,959 & 0,948 & 0,797 & 0,893 & 0,298 \\
\hline & PU2 & 0,924 & & & & & \\
\hline & PU3 & 0,910 & & & & & \\
\hline & PU4 & 0,929 & & & & & \\
\hline & PU5 & 0,826 & & & & & \\
\hline & PU6 & 0,896 & & & & & \\
\hline \multirow[t]{5}{*}{ PEOU } & PEOU1 & 0,860 & 0,935 & 0,914 & 0,744 & 0,862 & - \\
\hline & PEOU2 & 0,831 & & & & & \\
\hline & PEOU3 & 0,895 & & & & & \\
\hline & PEOU4 & 0,878 & & & & & \\
\hline & PEOU5 & 0,847 & & & & & \\
\hline \multirow[t]{4}{*}{ BI } & BI1 & 0,896 & 0,910 & 0,868 & 0,719 & 0,848 & 0,454 \\
\hline & $\mathrm{BI} 2$ & 0,900 & & & & & \\
\hline & $\mathrm{BI} 3$ & 0,738 & & & & & \\
\hline & BI4 & 0,847 & & & & & \\
\hline \multirow[t]{2}{*}{$\mathrm{AU}$} & AU1 & 0,848 & 0,851 & 0,650 & 0,704 & 0,839 & 0,055 \\
\hline & AU2 & 0,873 & & & & & \\
\hline
\end{tabular}

TABEL V

Nilai AKar AVE dAN NiLAi KorELASI ANTARKONSTRUK

\begin{tabular}{cllll}
\hline & AU & BI & PEOU & PU \\
\hline AU & $\mathbf{0 , 8 3 9 5}$ & & & \\
BI & 0.2360 & $\mathbf{0 , 8 4 8 2}$ & & \\
PEOU & 0.2167 & 0.5609 & $\mathbf{0 , 8 6 2 8}$ & \\
PU & 0.2702 & 0.6193 & 0.5460 & $\mathbf{0 , 8 9 3 1}$ \\
\hline
\end{tabular}

Pengujian selanjutnya dalam analisis model pengukuran (outer model) adalah menilai construct reliability. Reliabilitas konstruk merupakan tingkat konsistensi indikator dalam mengukur konstruk tertentu pada kondisi apapun tidak terikat pada waktu, lokasi maupun populasi. Construct reliability dapat diukur dengan nilai composite reliability dan cronbach alpha yang dihasilkan aplikasi SmartPLS. Suatu konstruk / variabel laten dinyatakan reliabel jika memiliki nilai composite reliability lebih besar dari 0,7 dan nilai cronbach alpha lebih besar dari 0,6. Tabel 4 memperlihatkan bahwa nilai composite reliability untuk semua konstruk / variabel laten lebih besar dari 0,7 serta nilai cronbach alpha untuk semua konstruk tersebut lebih besar dari 0,6 sehingga dapat dikatakan bahwa keseluruhan konstruk dalam penelitian ini merupakan konstruk yang reliabel.

Evaluasi model struktural dilakukan dengan melihat nilai R-square untuk setiap variabel laten endogenus sebagai kekuatan prediksi dari model struktural. Semakin tinggi nilai $\mathrm{R}$ square, maka 
semakin besar suatu variabel bebas dapat menjelaskan variabel terikatnya dan semakin baik persamaan strukturalnya. Kolom R Square pada Tabel 4 untuk variabel Perceived Usefulness dapat dijelaskan bahwa hanya $29,81 \%$ proporsi varian dari konstruk Perceived Usefuless yang dapat dijelaskan oleh variabel Perceived Ease of Use pada model penelitian, sedangkan sisanya $70,19 \%$ varian dapat dijelaskan oleh variabel lain yang tidak dibahas pada model penelitian ini. Kekuatan prediksi model struktural pada variabel PU ini tergolong lemah. Nilai R Square untuk variabel Behaviour Intention dapat diinterpretasikan bahwa sebanyak 45,42\% proporsi varian dari konstruk Behaviour Intention dapat dijelaskan oleh variabel Perceived Eae of Use dan variabel Perceived Usefulness, sedangkan sisasnya $58,58 \%$ varian dapat dijelaskan oleh variabel lain yang tidak dibahas dalam model penelitan ini. Kekuatan prediksi model struktural pada variabel BI ini tergolong moderat. Nilai R Square untuk variabel dapat diinterpretasikan bahwa hanya $5,57 \%$ proporsi varian dari konstruk Actual Usage yang dapat dijelaskan oleh variabel Behaviour Intention, sedangkan sisanya 94,93\% varian dapat dijelaskan oleh variabel lain yang tidak dibahas dalam model penelitian ini. Kekuatan prediksi model struktural pada variabel AU ini tergolong lemah. Diantara ketiga variabel endogenus yang ada pada model penelitian ini, variabel BI lebih dapat jelaskan oleh dua variabel eksogenusnya dibandingkan dengan variabel PU dan AU yang sedikit sekali berhasil dijelaskan oleh variabel eksogennya pada model penelitian ini.

Pengaruh hubungan variabel laten eksogenus terhadap variabel laten endogenus dapat pula dilihat dari nilai koefisien jalur (path coefisien) yang dihasilkan pada SmartPLS. Tabel 6 menunjukkan nilai koefisien jalur pada masingmasing hubungan antar variabel laten dan Tabel 7 menunjukkan hasil ringkasan pengujian hipotesis.

TABEL VI

Nilai Koefisien JaluUR Dan Hasil Pengujian Hipotesis

\begin{tabular}{cccc}
\hline & $\begin{array}{c}\text { Koefisien } \\
\text { Jalur }\end{array}$ & $\begin{array}{c}\text { Standard } \\
\text { Error } \\
\text { (STERR) }\end{array}$ & $\begin{array}{c}\text { T Statistik } \\
\text { (|O/STERR|) }\end{array}$ \\
\hline PEOU -> PU & 0.5460 & 0.0631 & 8.6593 \\
PEOU -> BI & 0.3174 & 0.0529 & 5.9991 \\
PU -> BI & 0.4460 & 0.0767 & 5.8113 \\
BI -> AU & 0.2360 & 0.0624 & 3.7811 \\
\hline
\end{tabular}

Pengaruh hubungan variabel laten eksogenus terhadap variabel laten endogenus pada TABEL VI dapat dijelaskan bahwa hubungan antara variabel laten PEOU dengan variabel laten PU memiliki nilai koefisien jalur sebesar 0,5460 dengan t-statistik sebesar 8,6593 yang lebih dari nilai t tabel 2,58 untuk tingkat signifikansi $1 \%$, sehingga dapat dikatakan PEOU memiliki pengaruh terhadap PU. Nilai koefisien jalur yang positif menunjukkan bahwa nilai PEOU berbanding lurus dengan nilai PU. Untuk setiap kenaikan satu ukuran pada PEOU akan menaikkan ukuran PU sebanyak 0,5460. Hubungan antara variabel laten PEOU dengan variabel laten BI memiliki nilai koefisien jalur sebesar 0,3174 dengan t-statistik sebesar 5,9991 yang lebih besar dari nilai t tabel 2,58 untuk tingkat signifikansi $1 \%$, sehingga dapat dikatakan PEOU memiliki pengaruh terhadap BI. Nilai koefisien jalur yang positif menunjukkan bahwa nilai PEOU berbanding lurus dengan nilai BI. Variabel BI juga memiliki hubungan dengan variabel PU dengan nilai koefisien jalurnya sebesar 0,4450 dan t statistik sebesar 5,8113 yang lebih besar dari nilai t tabel 2,58 untuk tingkat signifikansi $1 \%$ sehingga dapat dikatakan variabel PU memiliki pengaruh terhadap BI. Nilai koefisien jalur yang positif menunjukkan bahwa nilai PU berbandng lurus dengan nilai BI. Mengingat variabel BI dipengaruhi oleh variabel PEOU dan juga variabel PU, andaikata nilai PEOU tetap maka untuk setiap kenaikan satu ukuran nilai PU akan menaikkan nilai BI sebesar 0,446, atau andaikata nilai PU tetap maka untuk setiap kenaikan satu ukuran nilai PEOU akan menaikkan nilai BI sebesar 0,317. Hubungan antara variabel laten $\mathrm{BI}$ dengan variabel laten $\mathrm{AU}$ memiliki nilai koefisien jalur sebesar 0,236 dengan t-statistik sebesar 3,7811 yang lebih besar dari nilai t tabel 2,58 untuk tingkat signifikansi $1 \%$, sehingga dapat dikatakan BI memiliki pengaruh terhadap AU. Nilai koefisien jalur yang positif menunjukkan bahwa nilai BI berbanging lurus dengan nilai AU. Untuk setiap kenaikan satu ukuran nilai BI akan menaikkan AU sebesar 0,236 .

Tabel VII

RINGKASAN KESIMPULAN HIPOTESIS

\begin{tabular}{|c|c|}
\hline Hipotesis & $\begin{array}{c}\text { Hasil } \\
\text { penguiian }\end{array}$ \\
\hline $\begin{array}{l}\text { H1 Persepsi kegunaan (Perceived Usefulness) } \\
\text { akan berpengaruh secara positif terhadap } \\
\text { niat menggunakan TI pada Pemerintah } \\
\text { Kota Bogor }\end{array}$ & $\begin{array}{l}\text { Signifikan, } \\
\text { diterima }\end{array}$ \\
\hline $\begin{array}{l}\text { H2 Persepsi kemudahan penggunaan } \\
\text { (Perceived Ease Of Use) akan } \\
\text { berpengaruh secara positif terhadap niat } \\
\text { menggunakan TI pada Pemkot Bogor }\end{array}$ & $\begin{array}{l}\text { Signifikan, } \\
\text { diterima }\end{array}$ \\
\hline $\begin{array}{l}\text { H3 Persepsi kemudahaan penggunaan } \\
\text { (Perceived Ease Of Use) akan } \\
\text { berpengaruh secara positif terhadap } \\
\text { persepsi kegunaan (Perceived Usefulness) }\end{array}$ & $\begin{array}{l}\text { Signifikan, } \\
\text { diterima }\end{array}$ \\
\hline $\begin{array}{l}\text { H4 Niat/Minat menggunakan TI (Behavioral } \\
\text { Intention) akan berpengaruh secara positif } \\
\text { terhadap Penggunaan TI secara nyata } \\
\text { (Actual Use) di Pemkot Bogor }\end{array}$ & $\begin{array}{l}\text { Signifikan, } \\
\text { diterima }\end{array}$ \\
\hline
\end{tabular}




\section{Pembahasan}

Hubungan antara Persepsi Kegunaan dengan Niat menggunakan TI pada Pemerintah Kota Bogor

Dari hasil uji hipotesis yang dilakukan, terdapat bukti empirik yang menyatakan bahwa Persepsi Kegunaan (Perceived Usefulness) memiliki pengaruh positif yang signifikan terhadap niat dalam menggunakan TI (Behavioural Intention) pada Pemerintah Kota Bogor. Niat penggunaan TI di kalangan pegawai Pemerintah Kota Bogor dipengaruhi oleh persepsi pegawai terhadap kegunaan atau manfaat yang ditimbulkan dari TI. Semakin pegawai merasa bahwa TI dapat menghasilkan manfaat, maka semakin besar niat mereka untuk menggunakan TI di lingkungan kerja. Persepsi akan manfaat / kegunaan TI yang dirasakan oleh para pegawai Pemerintah Kota Bogor dalam hal ini adalah manfaat yang berkaitan dengan pekerjaan, karena sebagaimana penelitian Hamner \& Qazi [14] manfaat atau keuntungan yang didapat dari TI bisa dipersepsikan juga sebagai manfaat atau keuntungan pribadi (Personal Utility) seperti adanya kompensasi finansial.

Hasil temuan pada uji hipotesis yang menyatakan bahwa Persepsi kegunaan (Perceived Usefulness) akan berpengaruh secara positif terhadap niat menggunakan TI pada Pemerintah Kota Bogor ini mendukung / sesuai dengan hasil temuan Putra \& Tjahjono [8] yang menyatakan bahwa manfaat (Perceived Usefulness) memiliki pengaruh yang signifikan terhadap minat berperilaku (Behavioural Intention) pada aparatur Pemerintah Kota Yogyakarta. Hal ini juga sesuai dengan hasil yang diperoleh pada penelitian Hamner \& Qazi [14], dimana Perceived Usefulness mempengaruhi Behavioural Intention di kalangan pegawai pemerintahan di Pakistan. Disertasi Thompson [15] juga mengungkapkan hal yang sama bahwa Perceived Usefulness (PU) memiliki pengaruh positif terhadap Behaviour Intention (BI) pada organisasi pemerintahan di Jamaika.

Hubungan antara Persepsi Kemudahan Penggunaan TI dengan Niat Menggunakan TI pada Pemerintah Kota Bogor

Dari hasil uji hipotesis yang dilakukan, terdapat bukti empirik yang menyatakan bahwa Persepsi Kemudahan Penggunaan TI (Perceived Ease of Use) memiliki pengaruh positif yang signifikan terhadap niat dalam menggunakan TI (Behavioural Intention) pada Pemerintah Kota Bogor. Niat dalam menggunakan TI di kalangan pegawai Pemerintah Kota Bogor dipengaruhi oleh persepsi pegawai terhadap kemudahan dalam menggunakan TI, hal ini dapat diinterpresikan sebagai: jika pegawai merasa mudah dalam menggunakan TI maka akan timbul niat untuk menggunakannya. Semakin pegawai merasa bahwa menggunakan TI itu mudah maka semakin besar niat atau minatnya dalam menggunakan TI. Persepsi kemudahan yang dirasakan pegawai dalam menggunakan TI seperti yang tertera pada indikator pengukuran yang terbukti memiliki validitas dan reliabilitas tinggi adalah mudah dalam hal mempelajari sistem atau TI yang digunakan sehingga mereka manjadi cepat untuk terampil dalam menggunakannya.

Pada penelitian ini terbukti bahwa yang mempengaruhi niat atau minat dalam menggunakan TI pada Pegawai Pemerintah Kota Bogor tidak hanya persepsi pegawai mengenai kemudahan dalam menggunakan TI tetapi juga persepsi pegawai terhadap manfaat atau kegunaan yang dirasakan dari menggunakan TI. Jika dilihat dari besarnya hubungan pengaruh yang ditunjukkan oleh koefisien jalur dari masingmasing hubungan, hubungan Persepsi Kegunaan dengan Minat Menggunakan memiliki koefisien jalur lebih besar dari pada koefisien jalur pada hubungan Persepsi Kemudahan Penggunaan dengan Minat Menggunakan, sehingga dapat dikatakan bahwa Persepsi Kegunaan TI lebih berpengaruh terhadap minat dalam menggunakan TI dibandingkan dengan Persepsi Kemudahan Penggunaan. Hal ini sesuai dengan kondisi penggunaan TI pada pegawai Pemerintah Kota Bogor yang digambarkan oleh salah satu pejabat Kantor Komunikasi dan Informatika Kota Bogor pada wawancara di awal yang menyatakan bahwa jika harus membandingkan antara kemudahan pengoperasian yang dimiliki oleh suatu sistem TI dengan manfaat yang ditimbulkannya, pegawai Pemerintah Kota Bogor akan cenderung memilih manfaat yang ditimbulkan dari penggunaan TI sebagai alasan dari menggunakan TI. Hasil penelitian ini juga mendukung disertasi Thompson [15] yang dalam penelitiannya memperoleh bukti hubungan Perceived Usefulness (PU) memiliki pengaruh lebih kuat terhadap Behaviour Intention (BI) dari pada Perceived Ease of Use (PEOU).

\section{Hubungan antara Persepsi Kemudahan Penggunaan TI dengan Persepsi Kegunaan}

Dari hasil uji hipotesis yang dilakukan, terdapat bukti empirik yang menyatakan bahwa Persepsi Kemudahan Penggunaan TI (Perceived Ease of Use) memiliki pengaruh positif yang signifikan terhadap Persepsi Kegunaan (Perceived 
Usefulness). Hal ini dapat diinterpretasikan jika para pegawai merasa bahwa menggunakan TI itu mudah maka akan menimbulkan persepsi juga di kalanngan pegawai bahwa penggunaan TI dapat bermanfaat. Semakin pegawai merasa mudah menggunakan TI, semakin besar pula persepsinya akan kegunaan atau manfaat yang ditimbulkan dari TI. Hasil penelitian ini mendukung hasil penelitian pada disertasi Thompson [15] yang menggambarkan penerimaan TI di kalangan pegawai pemerintahan di Jamaika, juga sesuai dengan hasil penelitian Putra \& Tjahjono [8] untuk pegawai pemerintah Kota Yogyakarta. Hasil yang sama juga diperoleh pada penelitian Hamner \& Qazi [14] di Pakistan, serta Santoso [7] dengan studi kasus pegawai Pemerintah Kabupaten Sragen.

Pada penelitian ini diperoleh bukti empirik bahwa Persepsi Kemudahaan Penggunaan TI (Perceived Ease of Use) tidak hanya memiliki pengaruh terhadap Persepsi Kegunaan (Perceived Usefulness), tetapi juga memiliki pengaruh yang signifikan terhadap Niat Menggunakan (Behavioral Intention). Jika dilihat dari besarnya hubungan pengaruh ini dari koefisien jalur pada masing-masing hubungan, pengaruh Persepsi Kemudahan Penggunaan TI terhadap Persepsi Kegunaan lebih kuat dibandingkan dengan pengaruh Kemudahan Penggunaan TI terhadap Niat Menggunakan. Besarnya koefisien jalur pada masing-masing hubungan ini dapat diinterpretasikan sebagai berikut: untuk setiap kenaikan satu ukuran Persepsi Kemudahan Penggunaan TI pada pegawai, akan menaikkan Persepsi Kegunaan TI sebesar 0,546 dan akan menaikkan niat dalam menggunaan TI sebesar 0,374, artinya jika persepsi pegawai akan kemudahan menggunakan TI ditingkatkan, maka akan menaikkan persepsi pegawai akan manfaat yang dihasilkan TI lebih besar dari naiknya minat untuk menggunakan TI.

\section{Hubungan antara Minat dalam Menggunakan TI dengan Penggunaan TI Secara Nyata}

Dari hasil uji hipotesis yang dilakukan, terdapat bukti empirik yang menyatakan bahwa Minat atau Niat dalam menggunakan TI (Behaviour Intention) memiliki pengaruh positif yang signifikan terhadap penggunaan TI secara nyata (Actual Use) yang merepresentasikan penerimaan TI. Walaupun pada penelitian ini tidak banyak varian data Actual Use yang berhasil dijelaskan oleh Behaviour Intention (hanya $5,57 \%$ ), namun dari hasil uji hipotesis diperoleh nilai t-statistik sebesar 3,7811 yang lebih besar dari nilai t-tabel 2,58 untuk tingkat signifikansi $1 \%$ sehingga dapat dinyatakan bahwa memang terdapat pengaruh yang signifikan antara Behaviour Intention dan Actual Use.

Pada beberapa penelitian sebelumnya yang diacu dalam penelitian ini, model penerimaan TI yang digunakan digambarkan hanya sampai pada Niat atau Minat Menggunakan (Behaviour Intention) saja, namun ada juga yang sampai pada penerimaan TI atau penggunaan TI tanpa menggunakan variabel Behaviour Intention, walaupun demikian, model awal TAM yang dikemukakan oleh Davis et al. [5] menunjukkan hubungan antara varibel-variabel terhadap Behavioural Itention dan Behavioural Intention terhadap Actual Use, sehingga hasil penelitian ini mendukung teori TAM pada Davis et al. [5] kaitannya dengan pengaruh positif yang signifikan antara Behavioural Intention terhadap Actual Use yang juga sesuai dengan teori TAM selanjutnya seperti TAM2, dan TAM3 [16].

\section{Kesimpulan, Keterbatasan, Saran}

Hasil pengolahan data membuktikan bahwa Persepsi Kegunaan (Perceived Usefulness) dan Persepsi Kemudahan Penggunaan (Perceived Ease of Use) memiliki pengaruh yang signifikan terhadap niat menggunakan TI (Behavioural Intention) pada Pemerintah Kota Bogor. Niat menggunakan TI (Behavioural Intention) memiliki pengaruh yang signifikan terhadap penggunaan TI secara nyata (Actual Use), dan Persepsi Kemudahan Penggunaan (Perceived Ease of Use) memiliki pengaruh yang signifikan terhadap Persepsi Kegunaan (Perceived Usefulness). Hasil pengolahan data juga memperlihatkan bahwa Persepsi Kegunaan memiliki pengaruh lebih tinggi terhadap niat menggunakan TI dari pada Persepsi Kemudahan Penggunaan TI. Persepsi Kemudahaan Penggunaan TI memiliki pengaruh positif yang signifikan terhadap Persepsi Kegunaan dan besar pengaruhnya lebih kuat dari pada pengaruh Persepsi Kemudahan Penggunaan TI terhadap Niat menggunakan TI. Faktor faktor individu yang mempengaruhi penerimaan TI pada Pemerintah Kota Bogor antara lain: Persepsi Kegunaan (Perceived Usefulness), Persepsi Kemudahan Penggunaan (Perceived Ease of Use), serta Niat Menggunakan (Behaviour Intention).

Penelitian ini hanya menelaah faktor-faktor individu yang mempengaruhi penerimaan TI di Pemerintah Kota Bogor. Variabel yang digunakan pada penelitian ini merujuk kepada penelitian yang pernah dilakukan sebelumnya yang disesuaikan dengan kondisi yang ada di Pemerintah Kota Bogor berdasarkan asumsi penulis. Jumlah responden juga hanya terbatas pada pegawai struktural dan tergolong minim jika 
dibandingkan dengan jumlah pegawai Pemkot Bogor secara keseluruhan (410 data observasi dari jumlah populasi 8850). Pada penelitian ini tidak dilakukan penggalian informasi di awal penelitian mengenai faktor-faktor individu apa saja yang diduga dapat mempengaruhi penerimaan TI di Pemkot Bogor karena terhambat keterbatasan waktu. Penelitian ini akan lebih lengkap jika sebelumnya dilakukan penggalian informasi mengenai faktor-faktor tersebut dan dijustifikasi oleh para pihak yang berkepentingan di Pemerintah Kota Bogor.

Penelitian selanjutnya terkait penerimaan TI di Pemkot Bogor dapat dilakukan dengan lebih spesifik memperhatikan faktor-faktor penerimaan pengguna terhadap sistem aplikasi tertentu dengan sebelumnya melakukan penggalian informasi mengenai faktor-faktor tersebut yang dijustifikasi oleh para pihak yang berkepentingan di Pemerintah Kota Bogor. Adapun saran yang dapat diberikan kepada Pemerintah Kota Bogor antara lain: Kaitannya dengan Perceived Usefulness (Persepsi kegunaan), Pemkot Bogor dapat terus melakukan kegiatan sosialisasi pemanfaatan TI kepada pegawai Pemkot Bogor untuk meningkatkan pemahaman pegawai akan manfaat yang dapat ditimbulkan dari penggunaan TI sehingga dapat meningkatkan penerimaan TI pada pegawai di Pemkot Bogor; Kaitannya dengan Perceived Ease of Use (Persepsi kemudahan penggunaan), Pemkot Bogor dapat terus melakukan kegiatan pelatihan penggunaan TI kepada pegawai untuk meningkatkan keterampilan dan kemampuan pengguna sehingga pegawai dapat dengan mudah menggunakan TI dan dapat meningkatkan penerimaan TI pada pegawai Pemkot Bogor.

\section{Referensi}

[1] Sang, S., \& Lee, J.-D, “A Conceptual Model of e-Government Acceptance in Public Sector", The International Conference on Digital Society, pp. 71-76. 2009.

[2] Quadahi, J., "A Qualitative Analysis of Factors Associated with User Acceptance and Rejection of a New Workplace Information System in the Public Sector: A Conceptual Model", Canadian Journal of Administrative Sciences, 201-213. 2008.

[3] Yamin, M., \& Lee, Y., "Level of Acceptance dan Factors Influencing Students' Intention to Use UCSI University's E-mail System”, International Conference on User Science Engineering (i-USEr), pp. 26-31. 2010.

[4] Navarro, J. G., Eldridge, S., Caro, E. M., \& Polo, M. T., "The Value of Estended Framework of TAM in the Electronic
Goverment Service", The Electronic Journal of Knowledge Management Volume, 402413. 2014.

[5] Davis, F. D., Bagozzi, R. P., \& Warshaw, P. R., "User Acceptance of Computer Technology: A Comparison of Two Theoretical Models", Management Science, 982-1003. 1989.

[6] Vencatachellum, I., \& Pudaruth, S., "Investigating E-Government Services Uptake in Mauritius: A User's Perspective", International Research Symposium in Service Management, pp. 1-19. 2010.

[7] Santoso, B., "Pengaruh Perceived Usefulness, Perceived Ease of Use, dan Perceived Enjoyment Terhadap Penerimaan Teknologi Infomasi (studi empiris di Kabupaten Sragen)", Jurnal Studi Akuntansi Indonesia, 1-15. 2012.

[8] Putra, G., \& Tjahjono, H. K., "Kajian Minat Berperilaku Aparatur Pemerintah Kota Dalam Menggunakan E-Government: Aplikasi Technology Acceptance Model (TAM)", National Conference on Management Research. 2008.

[9] Bogar, W., "The Ability of Human Resources in Supporting Regional Autonomy (A Study at Employees in SITARO Regency)", IOSR Journal of Business and Management (IOSR-JBM), 3744. 2013.

[10] Venkatesh, V., \& Bala, H., "Technology Acceptance Model 3 and a Research Agenda on Intervention", Journal Compilation, 273315. 2008.

[11] Selamat, Z., \& Jaffar, N., "Information Technology Acceptance: From Persfective of Malaysian Bankers", International Journal of Business and Management, 207217. 2011.

[12] Liao, C.-H., Tsou, C.-W., \& Shu, C.-W., "The Roles of Perceived Enjoyment and Price Perception in Determining Acceptance of Multimedia-on-Demand", International Journal of Business dan Information, 27-52. 2008.

[13] Latan, H., \& Ghozali, I.. Partial Least Squares Konsep, Teknik dan Aplikasi SmartPLS 2.0 M3. Badan Penerbit Universitas Diponegoro. 2012.

[14] Hamner, M., \& Qazi, R.-u.-R., "Expanding the Technology Acceptance Model to Examine Personal Computing Technology Utilization in Government Agencies in Developing Countries", Government Information Quarterly, 128-136. 2009.

[15] Thompson, T. I. "Assessing the Determinants of Information Technology 
Adoption in Jamaica's Public Sector Using the Technology Acceptance Model", ProQuest LLC. 2010.

[16] Venkatesh, V., \& Davis, F. D., “A Theoretical Extention of The Technology
Acceptance Model: Four Longitudinal Field Studies. Management Science, 186-204. 2000.

\section{Lampiran}

LAMPIRAN TABEL I

Matriks Kovarians, Mean, Simpangan Baku, Varian PU1 PU2 PU3 PU4 PU5 PU6 PEOU1 PEOU2 PEOU3 PEOU4 PEOU5 BI1 BI2 BI3 BI4 AU1 AU2

\begin{tabular}{|c|c|c|c|c|c|c|c|c|c|c|c|c|c|c|c|c|c|}
\hline PU1 & .496 & .386 & .387 & .378 & .333 & .355 & .290 & .218 & .218 & .214 & .156 & .236 & .200 & .199 & .214 & .205 & .175 \\
\hline PU2 & .386 & .518 & .423 & .410 & .398 & .402 & .331 & .257 & .236 & .253 & .186 & .267 & .243 & .250 & 236 & .205 & 22 \\
\hline PU3 & .387 & .423 & .505 & .396 & .353 & .400 & .307 & .234 & .227 & .234 & .165 & .263 & .232 & .243 & .253 & .211 & .182 \\
\hline PU4 & .378 & .410 & .396 & .458 & .379 & .374 & .302 & .224 & .221 & .215 & .168 & .253 & .246 & .236 & .240 & .212 & .210 \\
\hline PU5 & .333 & .398 & .353 & .379 & .585 & .391 & .316 & .249 & .238 & .232 & .183 & .250 & .243 & .249 & .234 & .135 & .150 \\
\hline PU6 & .355 & .402 & .400 & .374 & .391 & .502 & .308 & .241 & .217 & .231 & .178 & .247 & .236 & .252 & .243 & .174 & .212 \\
\hline PEOU1 & .290 & .331 & .307 & .302 & .316 & .308 & .615 & .468 & .434 & .398 & .380 & .261 & .227 & .257 & .222 & .226 & .123 \\
\hline PEOU2 & .218 & .257 & .234 & .224 & .249 & .241 & .468 & .877 & .586 & .407 & .465 & .243 & .213 & .275 & .246 & .228 & .165 \\
\hline PEOU3 & .218 & .236 & .227 & .221 & .238 & .217 & .434 & .586 & .679 & .441 & .450 & .257 & .223 & .254 & .252 & .231 & .152 \\
\hline PEOU4 & .214 & .253 & .234 & .215 & .232 & .231 & .398 & .407 & .441 & .525 & .393 & .261 & .226 & .232 & .247 & .157 & .120 \\
\hline PEOU5 & .156 & .186 & .165 & .168 & .183 & .178 & .380 & .465 & .450 & .393 & .583 & .206 & .186 & .228 & .209 & .179 & .111 \\
\hline BI1 & .236 & .267 & .263 & .253 & .250 & .247 & .261 & .24 & .25 & .261 & .206 & .448 & .357 & .325 & .308 & .177 & .16 \\
\hline BI2 & .200 & .243 & .232 & .246 & .243 & .236 & .227 & .213 & .223 & .226 & .186 & .357 & .455 & .371 & .306 & .109 & .162 \\
\hline BI3 & .199 & .250 & .243 & .236 & .249 & .252 & .257 & .275 & .254 & .232 & .228 & .325 & .371 & .889 & .333 & .171 & .236 \\
\hline BI4 & .214 & .236 & .253 & .240 & .234 & .243 & .222 & .246 & .252 & .247 & .209 & .308 & .306 & .333 & .470 & .146 & .15 \\
\hline AU1 & .205 & .205 & .211 & .212 & .135 & .174 & .226 & .228 & .231 & .157 & .179 & .177 & .109 & .171 & .146 & 1.579 & .81 \\
\hline AU2 & .175 & .221 & .182 & .210 & .150 & .212 & .123 & .165 & .152 & .120 & .111 & .169 & .162 & .236 & .154 & .811 & .793 \\
\hline Mean & 5.35 & 5.34 & 5.34 & 5.35 & 5.18 & 5.31 & 4.9 & 4.6 & 4.7 & 4.88 & 4.82 & 5.21 & 5.16 & 4.98 & 5.12 & 5.28 & 4.9 \\
\hline $\begin{array}{l}\text { Std. } \\
\text { Deviation }\end{array}$ & .704 & .720 & .711 & .676 & .765 & .708 & .78 & .937 & .82 & .724 & .764 & .670 & .674 & .943 & .686 & 25 & 1.33 \\
\hline Variance & .496 & .518 & .505 & .458 & .585 & .502 & .615 & .877 & .67 & .525 & .583 & .448 & .455 & .889 & .470 & 1.57 & .79 \\
\hline
\end{tabular}

LAMPIRAN TABEL II

MATRIKS KORELASI, MEAN, SIMPANGAN BAKU, VARIAN

PU1 PU2 PU3 PU4 PU5 PU6 PEOU1 PEOU2 PEOU3 PEOU4 PEOU5 BI1 BI2 BI3 BI4 AU1 AU2

\begin{tabular}{|c|c|c|c|c|c|c|c|c|c|c|c|c|c|c|c|c|c|}
\hline PU1 & 000 & 762 & .773 & .793 & .618 & .712 & .525 & .331 & .376 & .420 & .289 & .501 & .421 & .300 & .442 & .232 & .186 \\
\hline - & .762 & 1.000 & .828 & .841 & . & .788 & .586 & .381 & .398 & .484 & .338 & .554 & .500 & .369 & .479 & .226 & .230 \\
\hline & .773 & .828 & 1.000 & .823 & .649 & .79 & & .3 & .38 & & .304 & .554 & & .363 & & .236 & .192 \\
\hline U4 & .793 & .841 & .823 & 1.000 & .732 & .78 & .570 & .35 & .39 & .43 & .326 & .558 & .5 & .370 & .518 & .249 & .231 \\
\hline PU5 & .618 & .722 & .649 & .732 & 1.000 & .721 & .527 & .348 & .377 & .419 & .314 & .487 & .470 & .345 & 445 & .140 & .147 \\
\hline 6 & .712 & .788 & .795 & .781 & .721 & 1.000 & .554 & .36 & .37 & .4 & .329 & .520 & .4 & .377 & 9 & .196 & .223 \\
\hline PEO & .525 & .586 & .550 & .570 & .527 & .554 & 1.000 & .637 & .671 & .700 & .634 & .497 & .429 & .347 & .413 & .230 & .117 \\
\hline PEOU2 & .331 & .381 & .352 & .353 & .34 & .36 & 37 & 00 & .759 & .5 & .651 & .388 & .3 & .3 & 3 & .193 & .131 \\
\hline PEOU3 & .376 & .398 & .388 & .397 & .377 & .371 & .671 & .759 & 1.000 & .739 & .715 & .466 & .401 & .326 & .445 & .223 & .138 \\
\hline $\mathrm{P}$ & .420 & .4 & .454 & .438 & .41 & .45 & 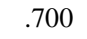 & 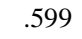 & (15) & 1.000 & .710 & .537 & 2 & .339 & .497 & .172 & .123 \\
\hline PEOU5 & .289 & .338 & .304 & .326 & .314 & .329 & .634 & .651 & .715 & .71 & 1.000 & .403 & .361 & .316 & .400 & .187 & .109 \\
\hline B & .501 & .554 & .554 & .558 & .48 & .52 & . & .388 & .466 & I. & .403 & 1.000 & .791 & .515 & .671 & .211 & .189 \\
\hline BI2 & .421 & .500 & 484 & .539 & 470 & 493 & 420 & .338 & .401 & .46 & .361 & .791 & 1.000 & .583 & .662 & .128 & .179 \\
\hline $\mathrm{BI}$ & .300 & .369 & .363 & .370 & .345 & .377 & .347 & .311 & .326 & .33 & .316 & .515 & .583 & 1.000 & .515 & .144 & .187 \\
\hline $\mathrm{BI} 4$ & .442 & .479 & .519 & .518 & .445 & .499 & .4 & .383 & .445 & .45 & .400 & .671 & .6 & .515 & 1.000 & .170 & .168 \\
\hline AU1 & .232 & .226 & .236 & .249 & .140 & .196 & .230 & .193 & .223 & .172 & .187 & .211 & .128 & .144 & .170 & 1.000 & .482 \\
\hline AU2 & .186 & .230 & .192 & .231 & .147 & .223 & .117 & .131 & .138 & .123 & .109 & .189 & .179 & .187 & .168 & .48 & 1.000 \\
\hline Mean & .35 & 5.34 & 5.34 & 5.35 & 5.18 & 5.31 & 4.90 & 4.65 & 4.77 & 4.88 & 4.82 & 5.21 & 5.16 & 4.98 & 5.12 & 5.28 & 4.94 \\
\hline
\end{tabular}


32 Journal of Information Systems, Volume 11, Issue 1, April 2015

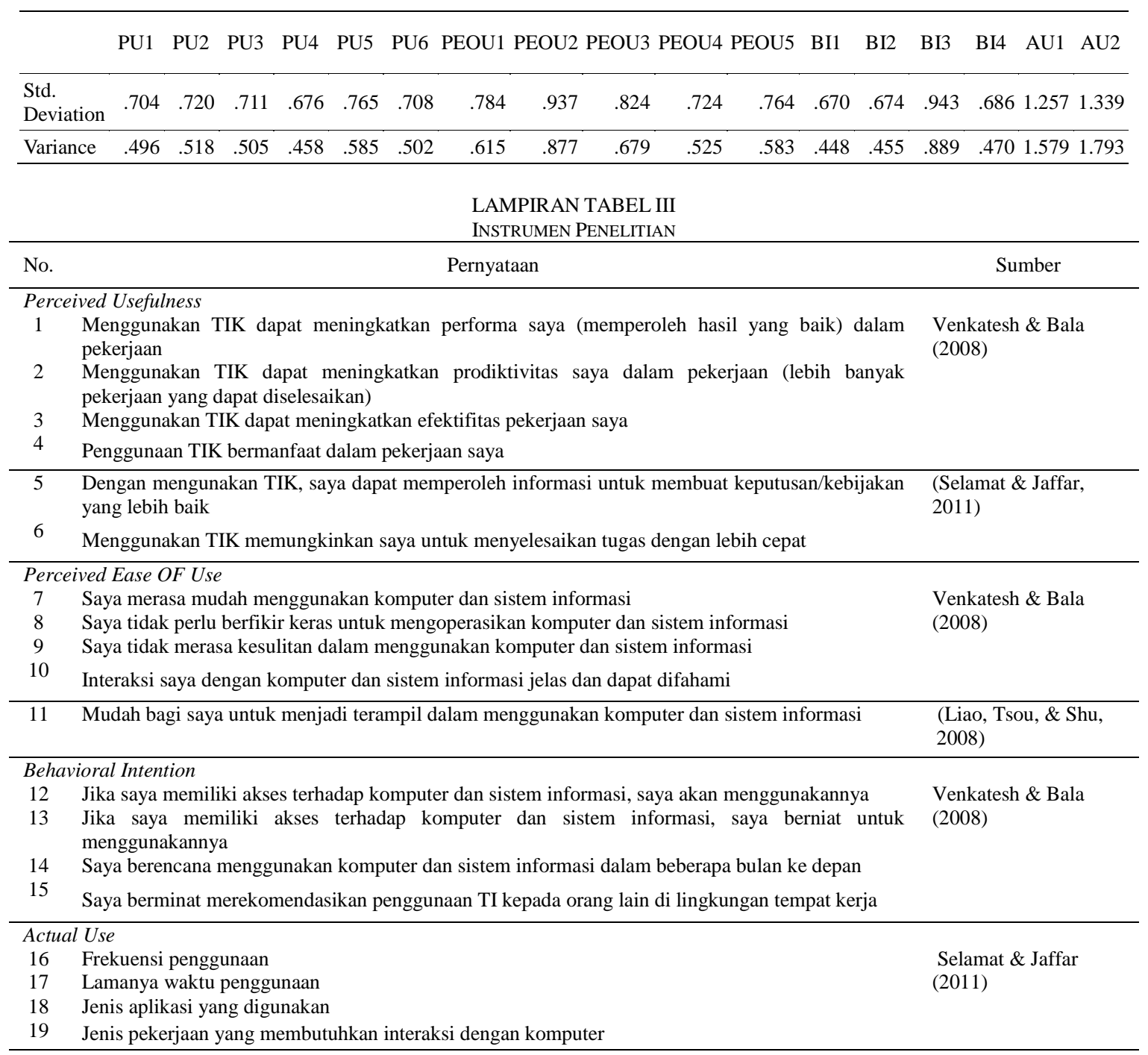

